\title{
SPECTRUM OF INTRACRANIAL TUBERCULOSIS ON MAGNETIC RESONANCE IMAGING
}

\author{
J. S. Aswini Jyothi' ${ }^{1}$ Immani Sreevani ${ }^{2}$
}

${ }^{1}$ Assistant Professor, Department of Radiology, Osmania Medical College and Hospital, Hyderabad.

${ }^{2}$ Senior Resident, Department of Radiology, Osmania Medical College and Hospital, Hyderabad.

\section{ABSTRACT}

\section{BACKGROUND}

Tuberculosis (TB) of the Central Nervous System (CNS) is a common infection, especially in the underdeveloped and developing countries accounting for a major health problem. Its incidence is on rise in developed nations too with the emergence of AIDS. A common manifestation of CNS tuberculosis is leptomeningitis, while other manifestations of CNS-TB are focal parenchymal granulomas (eg: tuberculomas), tuberculous abscesses, tuberculous cerebritis and pachymeningitis.

\section{AIMS}

1. To determine MR imaging criteria for the diagnosis of suspected intra cranial tuberculosis.

2. To differentiate tuberculomas into various MR morphologic types.

3. To observe MRS features of intracranial tuberculomas and tubercular abscesses.

4. To analyse the importance of MRI in the diagnosis of varied presentations of tuberculosis of the brain.

\section{MATERIAL AND METHODS}

The prospective hospital based evaluation of MR imaging features of intracranial tuberculomas was carried out in the Department of Radiodiagnosis, Osmania General Hospital, from December 2012 to August 2014. We evaluated MRI findings of 75 cases of intracranial tuberculosis on the basis of CSF analysis and treatment response on 3 months and 6 months followup MR scanning.

\section{RESULTS}

Age range of patients in our present study was between 5 years to 66 years. The mean age in our study was 35.5 years. No significant difference in the distribution of cerebral tuberculosis among the two genders. Most common presentation was tuberculomas. Multiple lesions and ring enhancing lesions were common. Dot-target lesions were few. Enhancing capsule was thick and complete in majority of the lesions. On MRI most of the lesions were hypointense on T1WI and Iso to hypointense on T2WI with isointense rim. All the patients had Cho/ $\mathrm{cr}<3$, while large no. of cases revealed a Cho/cr $<2$. Lipid peaks were noted in large no. of patients. None of the patients showed serine peaks. On followup imaging most of the lesions showed no edema with decrease in size, however, complete resolution was seen in only few cases.

\section{CONCLUSION}

MRI along with MRS is an excellent, non-invasive investigation. Providing us complete morphological pattern of an intracranial tuberculoma and its various associated complications.

\section{KEYWORDS}

MRI, MRS, Tuberculosis, Leptomeningitis, Focal Parenchymal Granulomas (Eg: Tuberculomas), Tuberculous Abscesses, Tuberculous Cerebritis and Pachymeningitis.

HOW TO CITE THIS ARTICLE: Jyothi JSA, Sreevani I. Spectrum of intracranial tuberculosis on magnetic resonance imaging. J Evolution Med Dent Sci 2016;5(1):71-78, DOI: 10.14260/jemds/2016/17

\section{INTRODUCTION}

Tuberculosis (TB) of the Central Nervous System (CNS) is a common infection, especially in the underdeveloped and developing countries accounting for a major health problem. Its incidence is on rise in developed nations too with the emergence of AIDS. A common manifestation of CNS tuberculosis is leptomeningitis, while other manifestations of CNS-TB are focal parenchymal granulomas. (Eg: tuberculomas), tuberculous abscesses, tuberculous cerebritis and pachymeningitis.

Financial or Other, Competing Interest: None.

Submission 13-12-2015, Peer Review 14-12-2015,

Acceptance 30-12-2015, Published 04-01-2016.

Corresponding Author:

Dr. J. S. Aswini Jyothi,

Flat: 204, Vasavi Bhuvana Apts,

H: 8-3-981/1,3,4,6,8,10,11,

Srinagar Colony, Hyderabad-500037,

Telangana.

E-mail: jyothijs@yahoo.com

DOI:10.14260/jemds/2016/17
Patients often present with focal seizures. Clinical diagnosis can be difficult as clinical manifestations are wide and non-specific. Moreover, objective evidence of systemic tuberculosis may not be present in all the patients of CNS tuberculosis and history of exposure to tuberculosis may be absent in up to $70 \%$ of cases. Therefore, imaging has an important role in establishing the diagnosis, especially in intracranial tuberculoma.

Its diagnosis should be made promptly since any delay in starting anti tuberculosis drugs is associated with increased morbidity and mortality. Diagnostic imaging like MRI plays a crucial role in diagnosis because of its inherent sensitivity and specificity in detecting CNS lesions earlier than CT. In addition to conventional MRI imaging, diffusion imaging, and proton magnetic resonance spectroscopy techniques helps for better tissue characterization in CNS TB.

The current study reviews the role of various MRI techniques especially proton MR spectroscopy in the diagnosis and management of intracranial TB. 


\section{MATERIALS AND METHODS}

\section{Study Design}

The prospective hospital based study of MR imaging features of intracranial tuberculomas was carried out in the Department of Radiodiagnosis, Osmania General Hospital from December 2012 to August 2014.

We evaluated MRI findings of 75 cases of intracranial tuberculosis on the basis of CSF analysis and treatment response on 3 months and 6 months follow-up MR scanning. The study includes both children and adults (Age group between 5-66 years).

\section{Scan Protocol}

MR scan was performed on GE 1.5T MR scanner. Scan was obtained in supine position.

\section{Sequences}

Axial T1, T2, FLAIR and contrast enhanced MR (Axial, sagittal and coronal) images were obtained. Gadolinium MR contrast media (Omni scan) was given to the patients in the dose of 0.1$0.2 \mathrm{mmol} / \mathrm{kg}$ body weight intravenously.

Spectroscopy was done for those patients with single or multiple brain lesions detected on MRI. Spectrum is obtained with good fat and water suppression. Single voxel is performed with short echo time TE of 35 and multivoxel with TE of 144. The voxel is placed on the lesion so that it covers the maximum area of the lesion in single voxel.

Adjacent parenchyma is also included in multivoxel spectroscopy. Lesions adjacent to the bone were avoided. Initially straight axial $\mathrm{T} 2 \mathrm{~W}$ sequence or contrast MRI is done with $5 \mathrm{~mm}$ slice thinness and zero gap to localize the lesion. Saturation bands are applied outside the volume of interest to reduce spectral contamination. Line width is maintained at below 5 for single voxel and 7 for multivoxel with $99 \%$ water and good fat suppression.

Spectra obtained from all the patients were analyzed for various metabolite peaks like lipid, lactate, NAA, creatinine and choline on single voxel and standard metabolite ratios Cho/Cr and Cho/NAA on multivoxel spectroscopy.

\section{Inclusion Criteria}

After MR scanning was performed in all the patients with clinical suspicion of focal intracranial lesions suspicious of tuberculosis, following patients were finally included in the study: Patients with positive CSF analysis

\section{Exclusion Criteria}

Following patients were excluded from our study following an MR study

1. Non-responders to ATT.

\section{FOLLOW-UP}

The patients with clinical and radiological suspicion of intracranial tuberculosis were started on antituberculous treatment and was surgically intervened in,

1. No response to antituberculous therapy.

2. Neurological deterioration.

3. Mass effect causing imminent herniation.

Response to antituberculous treatment was considered if there was any of the following

1. Significant reduction in perilesional edema.
2. Significant reduction in size of the lesion, defined by a $33 \%$ reduction in maximum diameter of the largest lesion.

3. Reduction in number of lesions.

\section{OBSERVATIONS AND RESULTS}

In the evaluation of intracranial tuberculosis, MRI plays a crucial role because of its inherent sensitivity and specificity in detecting CNS tuberculosis and advanced techniques like MRS, which help in better tissue characterization.

From December 2012 to August 2014, all the cases referred to the Department of Radiodiagnosis, Osmania General Hospital for MRI scan of the brain suspecting intracranial tuberculosis and fulfilling into the inclusion criteria as described previously were evaluated.

Out of the 100 patients, 75 patients are included in the study and rest of the 25 patients were excluded from the study. Patients with positive clinical findings, positive CSF analysis for tubercular pathology are subjected to MRI and follow-up MRI was done at 3 and 6 months.

The diagnosis of tuberculosis was based on abnormal neurologic symptoms and signs, cerebrospinal fluid abnormalities compatible with TBM, the response to antituberculous treatment and negative bacterial culture and abnormalities on brain-imaging studies compatible with tuberculosis.

\section{Age Distribution}

We included both children and adults. Our patients fall in age group between 5 years to 66 years. The mean age in our study was 35.5 years. Most of our patients lie in the age group between 16-30 years (24 cases).

\begin{tabular}{|c|c|c|c|c|c|c|}
\hline $\begin{array}{c}\text { Age } \\
\text { Groups }\end{array}$ & $\begin{array}{c}\mathbf{0 - 1 5} \\
\text { yrs }\end{array}$ & $\begin{array}{c}\mathbf{1 5 - 3 0} \\
\text { yrs }\end{array}$ & $\begin{array}{c}\mathbf{3 0 - 4 5} \\
\text { yrs }\end{array}$ & $\begin{array}{c}\mathbf{4 5 - 6 0} \\
\text { yrs }\end{array}$ & $\begin{array}{c}\mathbf{> 6 0} \\
\text { Yrs }\end{array}$ & $\begin{array}{c}\text { Tot } \\
\text { al }\end{array}$ \\
\hline $\begin{array}{c}\text { No. of } \\
\text { cases }\end{array}$ & 19 & 24 & 19 & 10 & 3 & 75 \\
\hline $\begin{array}{c}\text { Percentage } \\
\text { of cases }\end{array}$ & $\begin{array}{c}25.33 \\
\%\end{array}$ & $32 \%$ & $\begin{array}{c}25.33 \\
\%\end{array}$ & $\begin{array}{c}13.33 \\
\%\end{array}$ & $\begin{array}{c}4.43 \\
\%\end{array}$ & $\begin{array}{c}100 \\
\%\end{array}$ \\
\hline \multicolumn{7}{|c|}{ Table 3: Age Distribution of Cases } \\
\hline
\end{tabular}

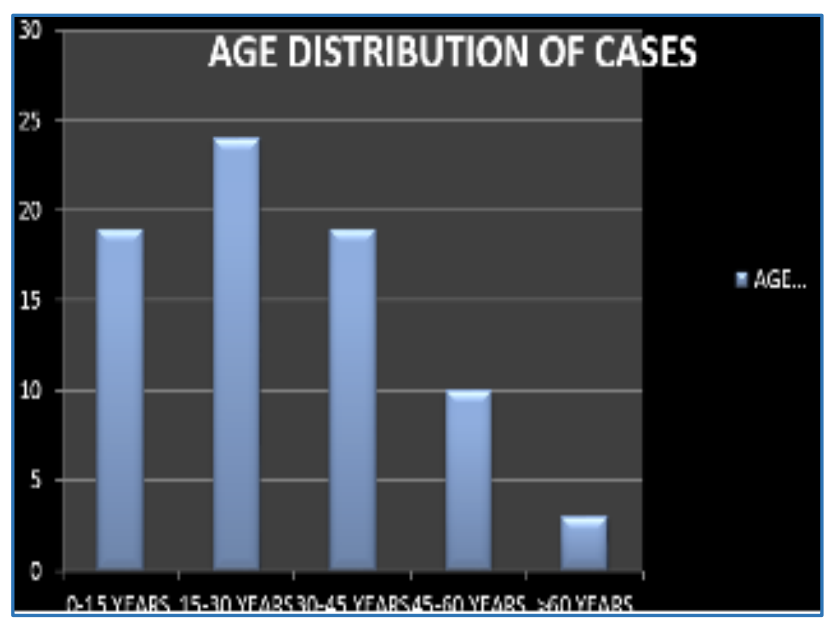

Gender Distribution

Predominant gender in our study are males, $\mathrm{n}=43(57.33 \%)$ as compared to females, $\mathrm{n}=32(42.66 \%)$. 


\begin{tabular}{|c|c|c|}
\hline $\begin{array}{c}\text { Gender } \\
\text { Distribution }\end{array}$ & Number of Cases & Percentage of Cases \\
\hline Males & 43 & $57.33 \%$ \\
\hline Females & 32 & $42.66 \%$ \\
\hline Total & 75 & $100 \%$ \\
\hline \multicolumn{2}{|c|}{ Table 4: Gender Distribution of Cases } \\
\hline
\end{tabular}

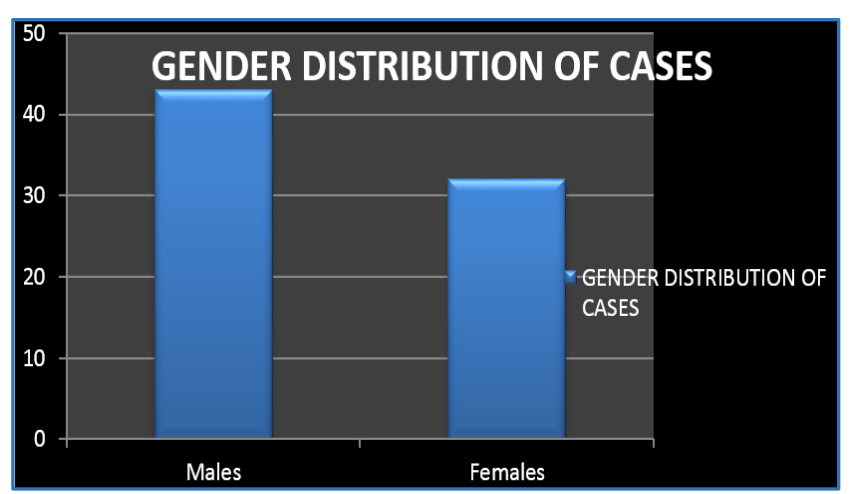

Distribution of Spectrum ff Tuberculosis

The varied presentations of Tuberculosis include Tuberculomas (58 cases), meningitis and hydrocephalus with or without association with tuberculomas (43 cases), tubercular abscess (1), vasculitis and infarction (11 cases).

\begin{tabular}{|c|c|}
\hline Spectrum of Tuberculosis & $\begin{array}{c}\text { Number of } \\
\text { Cases }\end{array}$ \\
\hline Tuberculomas & 58 \\
\hline $\begin{array}{c}\text { Total Tubercular meningitis and } \\
\text { hydrocephalus } \\
\text { (Isolated as well as associated with } \\
\text { tuberculoma) }\end{array}$ & 43 \\
\hline Tubercular abscess & 01 \\
\hline Vasculitis and Infarction & 11 \\
\hline Table 5: Distribution of Spectrum of Tuberculosis \\
\hline
\end{tabular}

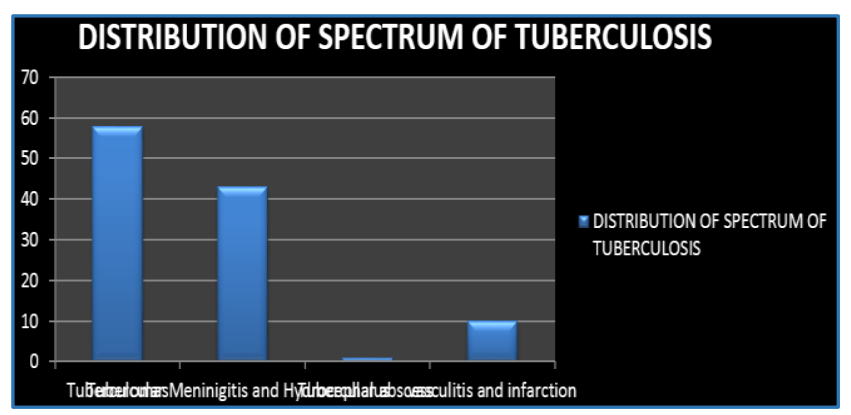

\section{Tuberculomas}

Out of the total 58 patients associated with tuberculomas, only tuberculomas are present in $30(51.7 \%)$ and tuberculomas are associated with complications in 28 (48.27\%).

\begin{tabular}{|c|c|c|}
\hline Tuberculomas & $\begin{array}{c}\text { Number of } \\
\text { Patients }\end{array}$ & $\begin{array}{c}\text { Percentage of } \\
\text { Patients }\end{array}$ \\
\hline Isolated tuberculomas & 30 & $51.7 \%$ \\
\hline $\begin{array}{c}\text { Tuberculomas } \\
\text { associated with } \\
\text { complications like } \\
\text { meningitis, vasculitis } \\
\text { and hydrocephalus }\end{array}$ & 28 & $48.27 \%$ \\
\hline Total & 58 & $100 \%$ \\
\hline \multicolumn{3}{|c|}{ Table 6: Distribution of Tuberculomas } \\
\hline
\end{tabular}

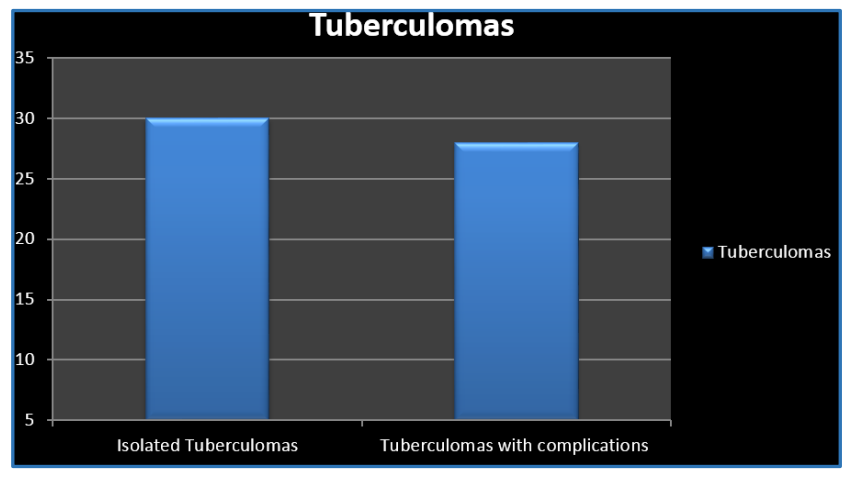

Number of Lesions (On Contrast Enhanced MRI)

Multiple lesions were noted in 34 patients (58.6\%). Solitary lesions were noted in rest 24 patients (41.3\%). Maximum number of lesions noted were 10 , found in 1 patient.

\begin{tabular}{|c|c|c|}
\hline $\begin{array}{c}\text { Number of } \\
\text { Lesions }\end{array}$ & $\begin{array}{c}\text { Number of } \\
\text { Cases }\end{array}$ & $\begin{array}{c}\text { Percentage of } \\
\text { Cases }\end{array}$ \\
\hline Multiple lesions & 34 & $58.6 \%$ \\
\hline Solitary lesions & 24 & $41.3 \%$ \\
\hline Total & $\mathbf{5 8}$ & $\mathbf{1 0 0 \%}$ \\
\hline \multicolumn{2}{|c|}{ Table 7: Distribution of Proportion of Multiple vs } \\
Solitary Lesions \\
\hline
\end{tabular}

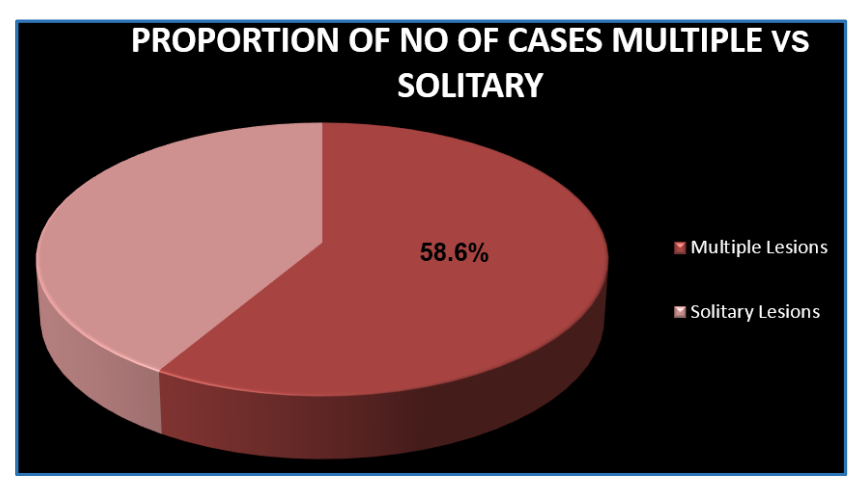

\begin{tabular}{|c|c|}
\hline Number of Lesions & Number of Patients \\
\hline 1 & 24 \\
\hline 2 & 9 \\
\hline 3 & 5 \\
\hline 4 & 5 \\
\hline 5 & 5 \\
\hline 6 & 3 \\
\hline 7 & 3 \\
\hline 8 & 3 \\
\hline 10 & 1 \\
\hline \multicolumn{2}{|c|}{ Table 8: Distribution of Number of Lesions } \\
\hline
\end{tabular}

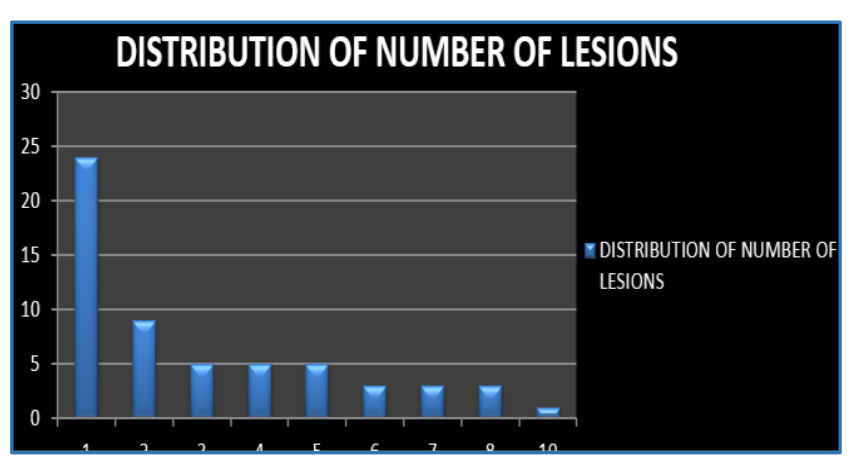




\section{IMAGING CHARACTERISTICS}

\section{Signal Characteristics}

One hundred and seventy five lesions from 75 patients were studied. MRI brain was analyzed keeping in mind the signal characteristics of the lesion on T1W1, capsule and centre signal intensities on T2WI and the enhancement pattern. Findings are described in the following table.

\begin{tabular}{|c|c|}
\hline Signal Characteristics & Number of Lesions \\
\hline T1WI & $44(28 \%)$ \\
\hline Iso & $109(62.28 \%)$ \\
\hline Hypo & $17(9.7 \%)$ \\
\hline Hyper & Capsule \\
\hline T2 WI & $78(45 \%)$ \\
\hline Iso & $75(43.16 \%)$ \\
\hline Hypo & $22(11.7 \%)$ \\
\hline Hyper & Centre \\
\hline T2 WI & $102(57.45 \%)$ \\
\hline Iso/Hypo & $73(42.5 \%)$ \\
\hline Hyper & Table 9: Signal Characteristics on MRI \\
\hline
\end{tabular}

Enhancement

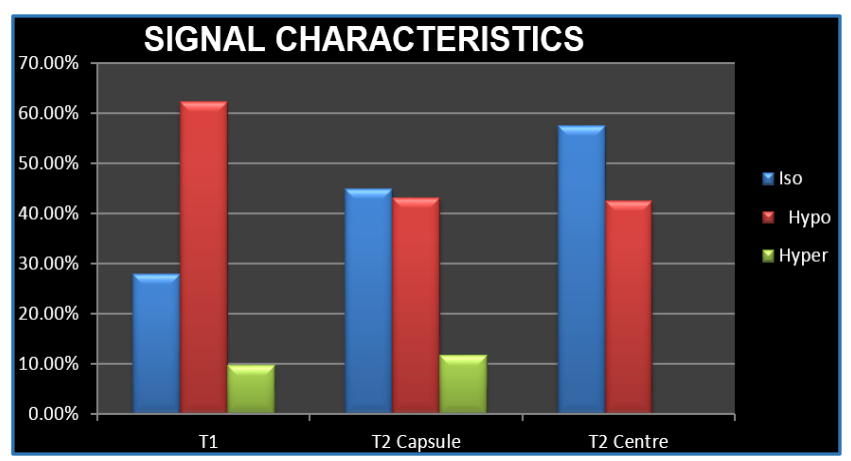

One hundred and seventy five lesions were evaluated from 58 cases of intracranial tuberculomas. Out of the 175 lesions, $71.3 \%$ of them are showing ring enhancement $(6.28 \%$ with central enhancing dot-target sign) and rest of the lesions show solid enhancement suggesting no central breakdown.

\begin{tabular}{|c|c|}
\hline TYPE OF ENHANCEMENT & NO. OF LESIONS \\
\hline Ring enhancement & $71.3 \%$ \\
\hline Solid & $23.3 \%$ \\
\hline Target & $6.28 \%$ \\
\hline Total & $\mathbf{1 0 0} \%$ \\
\hline \multicolumn{2}{|c|}{ Table 10: Type of Enhancement }
\end{tabular}

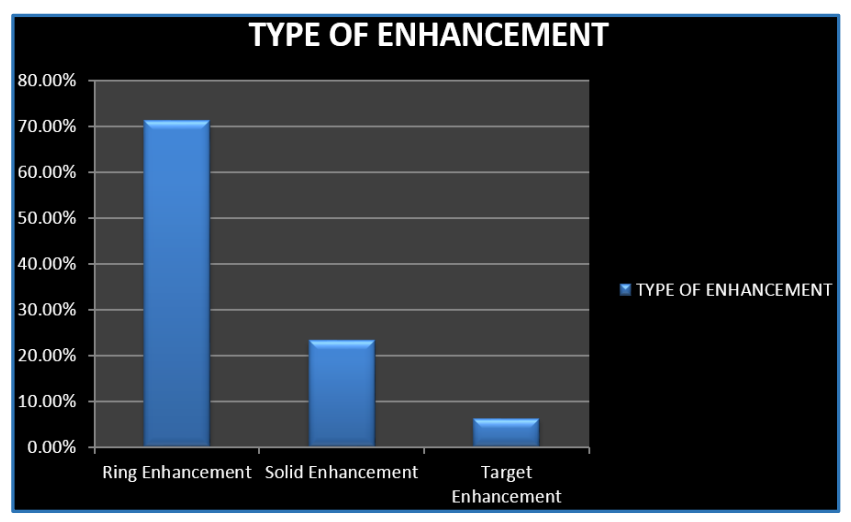

\section{Capsule Characteristics}

Capsule characteristics were studied in all the 175 lesions. Thickness of the capsule was arbitary as to the apperance. Capsule was thick in 170 lesions (97.14\%). The completeness of the capsule was seen in all the cases. This finding was evaluated on contrast enhanced imaging. Thickness of the capsule was uniform in 155 lesions $(88.57 \%)$ of the lesions, rest of the 20 lesions (11.53\%) show non-uniform capsule thickness.

\begin{tabular}{|c|c|c|}
\hline $\begin{array}{c}\text { CAPSULE } \\
\text { CHARACTERISTICS }\end{array}$ & $\begin{array}{c}\text { NUMBER OF } \\
\text { LESIONS }\end{array}$ & $\begin{array}{c}\text { PERCENTAGE } \\
\text { OF LESIONS }\end{array}$ \\
\hline Thickness & Thick -170 & $97.14 \%$ \\
\hline Completeness & Complete-175 & $100 \%$ \\
\hline Uniformity & Uniform -155 & $88.57 \%$ \\
\hline \multicolumn{2}{|c|}{ Table 11: Capsule Characteristics } \\
\hline
\end{tabular}

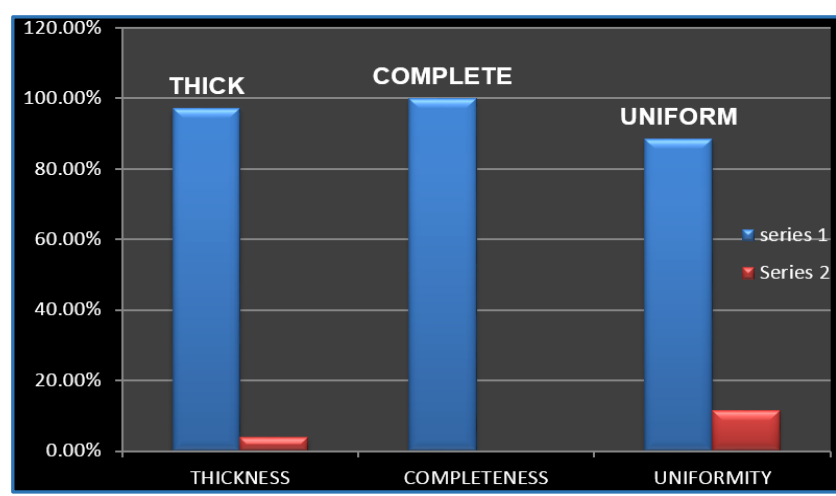

\section{MRS Characteristics}

Single and multivoxel MRS was performed in patients with emphasis on Cho/Cr ratio, lipid and lactate peaks and serine peaks. All the patients had $\mathrm{Cho} / \mathrm{cr}<3$, while 37 cases $(63.7 \%)$ revealed a $\mathrm{Cho} / \mathrm{Cr}<2$. Lipid peaks were noted in 48 cases (83\%) while 16 patients show lactate peaks $(27.58 \%)$. Both lipid and lactate peaks were noted in 11 cases (18\%). None of the patients showed serine peaks .

\begin{tabular}{|c|c|}
\hline MRS & $\begin{array}{c}\text { Number of Patients } \\
\text { (Percentage) }\end{array}$ \\
\hline Lipid peak & 48 cases $(83 \%)$ \\
\hline Lactate peak & 16 cases $(27.58 \%)$ \\
\hline Lipid + Lactate & 11 cases $(18 \%)$ \\
\hline Cho/Cr & 58 cases $(100 \%)$ \\
\hline$<3$ & 37 cases $(63.7 \%)$ \\
\hline$<2$ & Table 12: MRS Characteristics \\
\hline
\end{tabular}

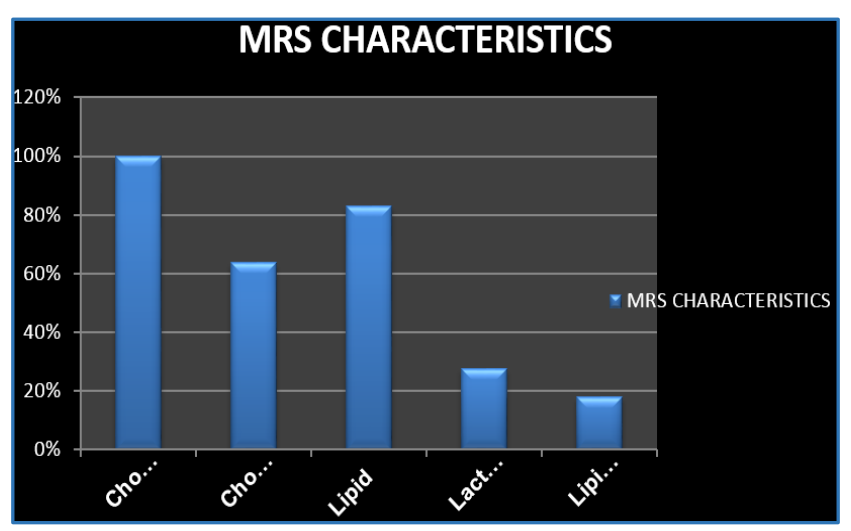


Conglomeration and Edema on MRI

Out of the 34 patients showing multiple lesions, conglomeration of the lesions was noted in 26 patients. Perilesional edema was defined into three grades: I, II, III as described below.

\begin{tabular}{|c|c|c|}
\hline Grade & Edema & $\begin{array}{c}\text { Number of } \\
\text { Patients } \\
\text { (Percentage ) }\end{array}$ \\
\hline Grade I & $\begin{array}{c}\text { Absent/minimal } \\
\text { edema around the } \\
\text { lesion }\end{array}$ & $9(15.6 \%)$ \\
\hline Grade II & Less than $4 \mathrm{cms}$ & $29(50 \%)$ \\
\hline $\begin{array}{c}\text { Grade } \\
\text { III }\end{array}$ & Lobar/hemispheric & $20(34.3 \%)$ \\
\hline \multicolumn{2}{|c|}{ Table 13: Distribution of Edema on MRI } \\
\hline \multicolumn{2}{|c}{}
\end{tabular}

All the cases show different grades of edema, grade I edema was in $9(15.6 \%)$ cases, grade II edema in 29 cases and grade III edema was noted in $20(34.3 \%)$ cases.

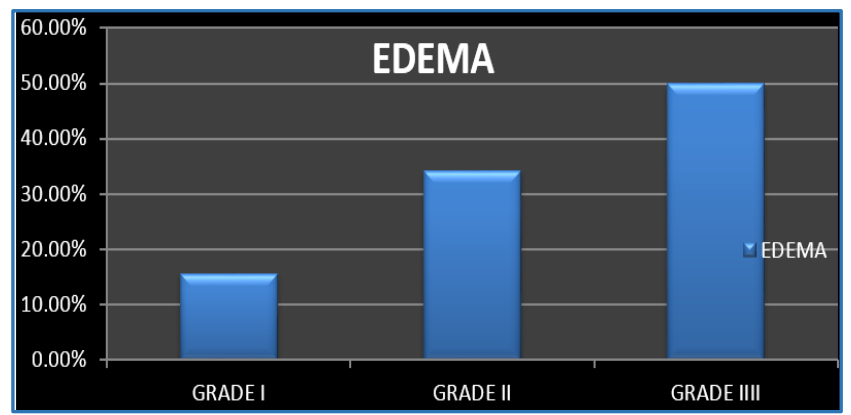

\section{Meningitis}

Out of the 43 patients presenting with meningitis (With or without tuberculomas), enhancing basal exudates were present in 40 (93\%) cases, progressive hydrocephalus in all the 43 cases and features of infarction are present in 12 (27\%).

\begin{tabular}{|c|c|c|}
\hline Features & $\begin{array}{c}\text { Number of } \\
\text { Cases }\end{array}$ & $\begin{array}{c}\text { Percentage of } \\
\text { Cases }\end{array}$ \\
\hline $\begin{array}{c}\text { Enhancing basal } \\
\text { exudates }\end{array}$ & 40 cases & $93 \%$ \\
\hline $\begin{array}{c}\text { Progressive } \\
\text { hydrocephalus }\end{array}$ & 43 cases & $100 \%$ \\
\hline Infarction & 12 cases & $27 \%$ \\
\hline
\end{tabular}

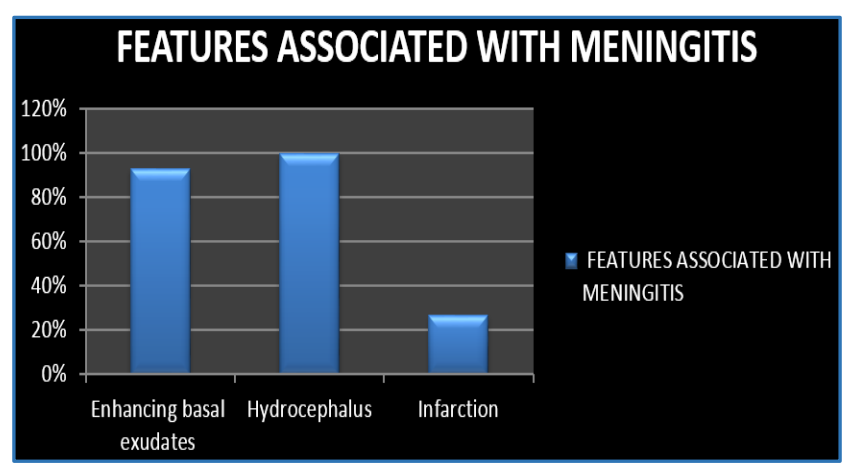

Hydrocephalus

Out of the 43 cases presenting with hydrocephalus, communicating hydrocephalus is present in $33(76.7 \%)$ and non-communicating (Obstructive hydrocephalus) is present in the rest 10 (23.25\%).

\begin{tabular}{|c|c|c|}
\hline Hydrocephalus & $\begin{array}{c}\text { Number of } \\
\text { Cases }\end{array}$ & $\begin{array}{c}\text { Percentage of } \\
\text { Cases }\end{array}$ \\
\hline $\begin{array}{c}\text { Communicating } \\
\text { hydrocephalus }\end{array}$ & 33 cases & $76.7 \%$ \\
\hline $\begin{array}{c}\text { Non-communicating } \\
\text { hydrocephalus }\end{array}$ & 10 cases & $23.25 \%$ \\
\hline \multicolumn{2}{|c|}{ Table 15: Distribution of Hydrocephalus } \\
\hline
\end{tabular}

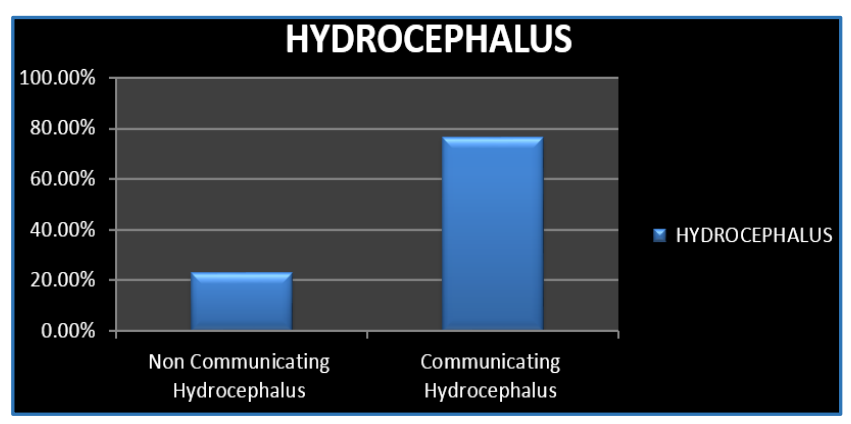

\section{FOLLOW-UP IMAGING}

Follow-up imaging at 3 and 6 months was performed for all the patients who had shown clinical response to ATT.

In case of tuberculomas, all the patients showed significant reduction in the perilesional edema, $77.7 \%$ patients revealed significant reduction in the size of the largest lesion (reduction by $33 \%$ of the greatest dimension of the lesion) and 12 of the patients showed near complete resolution of the lesion. Approximately 20 patients with Grade III edema were given steroids for the initial 2 weeks, for these a follow-up MR scan was also performed at 1 month which was not considered for evaluating response of treatment.

\begin{tabular}{|lc|c|c|}
\hline $\begin{array}{c}\text { Findings on follow-up } \\
\text { MRI in Tuberculomas }\end{array}$ & $\begin{array}{c}\text { Number of } \\
\text { Patients }\end{array}$ & Percentage \\
\hline 1) & Reduction in edema & 58 & $100 \%$ \\
\hline 2) & Reduction in size & 44 & $77.78 \%$ \\
\hline 3) & Complete resolution & 12 & $22.22 \%$ \\
\hline \multicolumn{3}{|c|}{ Table 16: Findings on follow-up MRI } \\
\hline
\end{tabular}

\section{LIMITATIONS OF THE STUDY}

1. Our study mainly relied on clinical and imageological improvement with antituberculous treatment.However, it is not possible to conclude on the final nature of the lesion as tuberculosis in these cases because some nontuberculous lesions can improve simultaneously with ATT. So a large sample may be subjected for analysis with proven biopsy.

2. Wider range of $\mathrm{Cho:Cr}$ ratios poses difficulty in determining a specific cut off to rule out intracranial tuberculomas.

3. Our study is not backed up with histopathological analysis in the case of tuberculomas.

\section{DISCUSSION}

Age and Number of Cases Studied

There was no specific age group selected in this study. We included both children and adults. Age range of patients in 
our present study was between 5 years to 66 years. The mean age in our study was 35.5 years.

Dastur. ${ }^{1}$ found that $50 \%$ of patients with tuberculosis in particular tuberculomas were below the age of $10,59 \%$ below the age of 15 years and $83 \%$ below the age of 25 years.

Bagchi A. ${ }^{2}$ Rao and Dinakar found tuberculomas in patients of all age groups, more frequently in first four decades of life.

Rammurthi. ${ }^{3}$ found that cases of tuberculomas were $40 \%$ in children.

Salgado et al. ${ }^{4}$ found that tuberculomas were found in all age groups with a mean age group of 30 years.

Uysal et al. ${ }^{5}$ found that median age for tuberculomas is 6 years.

\begin{tabular}{|c|c|c|}
\hline Series & $\begin{array}{c}\text { No. of } \\
\text { Patients }\end{array}$ & Age (Years) \\
\hline $\begin{array}{c}\text { Bhargava and } \\
\text { Tondon. }\end{array}$ & 25 & $\begin{array}{c}<30=19 \\
>30=6\end{array}$ \\
\hline Dastur. $^{1}$ & 40 & $\begin{array}{c}<10=50 \% \\
<15=59 \% \\
<25=83 \%\end{array}$ \\
\hline Rammurthi. $^{3}$ & 280 & $\begin{array}{c}40 \% \text { children, age not } \\
\text { specified }\end{array}$ \\
\hline Salgado et al. ${ }^{7}$ & 6 & Mean=30 15 -3years) \\
\hline Chang et al. & 26 & $5-65$ years \\
\hline Uysal et al. ${ }^{5}$ & 11 & Median age $=6$ years \\
\hline Present study & 75 & 5-66 years \\
\hline \multicolumn{2}{|c|}{ Table 17: Distribution of Age of Patients in Various } \\
Studies
\end{tabular}

\section{GENDER}

In a study conducted by Bhargav and Tondon. ${ }^{8}$ on 25 patients, $\mathrm{M}: \mathrm{F}$ ratio is $3: 2$.

In a study conducted by Salgado et al. ${ }^{4}$ on 6 patients, male-to-female ratio is $1: 2$.

In a study conducted by Uysal et al..$^{5}$ on 11 patients, maleto-female ratio is 7:4.

In the present study on 75 patients, there was no significant difference in the distribution of cerebral tuberculosis among the two genders (57\% males and $43 \%$ females).

\section{RADIOLOGICAL CORRELATION TUBERCULOMAS}

\section{A. Multiplicity of Lesions}

Post contrast MR studies may reveal multiple lesions in 34 cases $(58.7 \%)$ and solitary lesions are noted in rest of the 24 cases $(41.2 \%)$. Maximum number of lesions noted was 10 found in one patient. The final lesion count was performed on MR contrast study, so as not to overlook the lesions as described by Chang et al. ${ }^{7}$

Uysal et al. 5 conducted a study on 11 patients and multiple lesions are found in 5 patients (45.45\%). DJ Reddy. ${ }^{9}$ conducted a study on 5 patients, multiple lesions are found in 1 patient (20\%). Asenjo et al. ${ }^{10}$-conducted a study on 86 patients, multiple lesions are found in 33 cases (38.3\%).

Bhargava et al. ${ }^{6}$-conducted a study on 25 patients, multiple lesions are found in 55\% cases. Garg. ${ }^{8}$ found that single lesions are found in $66-73 \%$ of patients. Jinkins. ${ }^{11}$ in a study of 57 patients multiple lesions are found in 17 cases (29.8\%).
Vimala $\mathrm{Z}$ and Dinkar. ${ }^{7}$ conducted a study on 22 patients, multiple lesions are found in 5 cases $(22.7 \%)$.

\begin{tabular}{|c|c|c|}
\hline Series & $\begin{array}{c}\text { Number of } \\
\text { Patients }\end{array}$ & Multiplicity \\
\hline DJ Reddy. ${ }^{9}$ & 5, autopsy & Multiple=1(20\%) \\
\hline Asenjo et al. ${ }^{10}$ & 86, autopsy & Multiple $=33(38.3 \%)$ \\
\hline Bhargava et al. ${ }^{6}$ & 25 & Multiple $=55 \%$ \\
\hline Garg. ${ }^{8}$ & Review & Single $=66-73 \%$ \\
\hline Jinkins. $^{11}$ & 57 & $\begin{array}{c}\text { Multiple }=17 \\
(29.8 \%)\end{array}$ \\
\hline $\begin{array}{c}\text { Vimala } \mathrm{Z} \text { and } \\
\text { Dinkar. }^{7}\end{array}$ & 22 & Multiple $=5(22.7 \%)$ \\
\hline Present study & 58 & $\begin{array}{c}\text { Multiple }=34 \\
(58.7 \%)\end{array}$ \\
\hline
\end{tabular}

\section{B. MRI Characteristics}

MRI brain (Plain and contrast studies) were analysed for the signal characteristics of the capsule and the centre of the lesion and enhancement pattern

\begin{tabular}{|c|c|c|}
\hline Series & $\begin{array}{c}\text { No. of } \\
\text { Patients }\end{array}$ & MRI Features \\
\hline Garg. ${ }^{8}$ & Review & $\begin{array}{r}\text { T1-isointense to grey matter } \\
\text { T2-central hyperintensity } \\
\text { Enhancement-ring or solid }\end{array}$ \\
\hline $\begin{array}{c}\text { Salgado } \\
\text { et al. }{ }^{4}\end{array}$ & $\mathrm{~N}=6$ & $\begin{array}{c}\text { T1- Hypointense in all cases } \\
\text { T2-varied to stage of the disease }\end{array}$ \\
\hline $\begin{array}{c}\text { Chang } \\
\text { et al. }{ }^{12}\end{array}$ & $\mathrm{~N}=26$ & $\begin{array}{c}\text { T1, T2 -Isointense focal } \\
\text { hypointensity on T2 } \\
\text { conglomerated, ring enhancement } \\
\text { Thin ring - 2/5 }\end{array}$ \\
\hline \multicolumn{3}{|c|}{ Table 18: Signal Characteristics on MRI } \\
\hline
\end{tabular}

\section{Present Study}

On T1 the lesions were isointense in 49 (28\%), hypo in 109 (62.28\%) and hyper in 17 (9.7\%). On T2 capsule was observed as iso in $78(45 \%)$, hypo in $75(43.16 \%)$ and hyper in 22 (11.7\%). On T2 centre revealed iso/hypointensity in 102 $(57.45 \%)$ and hyperintensity in $73(42.5 \%)$ of the lesions.

Garg. ${ }^{8}$ found that lesions are isointense to grey matter on $\mathrm{T} 1$ with central hyperintensity on $\mathrm{T} 2$. On post-contrast enhancement is ring or solid.

Salgado et al. ${ }^{4}$ conducted a study on 6 patients. They found that lesions are hypointense in all cases on T1. T2 lesions varied with the stage of the disease.

Gupta et al. and Chang et al. ${ }^{12}$ described that the MR features of tuberculoma depend on whether the granuloma is non-caseating or caseating. The latter may be solid or liquid at the centre. Non-caseating granuloma are hypo on T1W and hyper on $\mathrm{T} 2 \mathrm{~W}$ images with homogenous enhancement on contrast.

Caseating granuloma with solid caseation appeared hypo to iso on T1 and iso to hypo on T2 images, the degree of hypointensity being dependent on regional fibrosis/gliosis by products of the inflammation like free radicals, macrophage and other cellular infiltrates. Gadolinium enhanced T1 images shows ring enhancement.

Caseating granulomas with central liquefaction were described as hypo on $\mathrm{T} 1$ and hyper on $\mathrm{T} 2$ with peripheral hypointense rim on $\mathrm{T} 2$ and rim enhancement on contrast. 


\section{Capsule Characteristics}

Capsule was thick in 170 lesions (97.4\%) in our study. The completeness of the capsule was seen in all the cases in our study. Uniform capsule thickness was seen in 155 lesions $(88.57 \%)$ in our study. Ozates et al. ${ }^{13}$ described that ring enhancement tends to be unbroken and is usually of uniform thickness.

\section{Conglomeration and Edema on MRI}

Out of the 34 patients showing multiple lesions, conglomeration of the lesions was noted in 26 patients (76\%).

All the cases show different grades of edema, grade I edema was noted in $9(15.6 \%)$ cases, grade II edema was noted in 29 cases and grade III edema was noted in 20 (34.3\%) cases. Perilesional edema was noted to be of lesser grade (Grade I or II) in brainstem lesions because of the compactness of the tissues in these sites. Perilesional edema was found to be of higher grades (Grade II and grade III) in patients with conglomeration.

\section{MR Spectroscopy}

Out of 58 patients, $48(83 \%)$ revealed lipid peaks and rest of the $10(17 \%)$ did not show lipid peaks. 16 cases $(27.58 \%)$ show elevated lactate peak and 11 cases (18\%) show elevated lipid and lactate peaks. The origin of these lipids could be contributed to lipid laden macrophages. In 37 out of the 58 cases, the choline/Cr ratio was less than 2 indicating minor, but significant neuronal loss.

Gupta RK, Pande R, Khan EM, et al. ${ }^{14}$ stated that the MRS of the tuberculoma demonstrates lipid peaks at $0.9,1.3,2.0$ and $2.8 \mathrm{ppm}$ and phosphoserine peak at $3.7 \mathrm{ppm}$.

\section{Meningitis}

Of the total 75 cases selected, $43(57.3 \%)$ presented with features of meningitis. Out of the 43 patients presenting with meningitis (with or without tuberculomas) in our present study, enhancing basal exudates were present in 40 (93\%) cases, progressive hydrocephalus was present in all the 43 cases and features of infarction are present in $12(27 \%)$ of cases. Rim Abdelmalek et al. ${ }^{15}$ retrospectively studied 29 cases of meningitis out of which MRI was definite in only 11 cases and presumptive in 18 cases.

\section{CONCLUSION}

Based on the preceding discussions following conclusions are drawn for MR diagnosis of intracranial tuberculomas.

\section{MR Features Suggestive of Intracranial Tuberculomas are}

1. Multiple lesions with/without conglomeration.

2. Signal intensity
a. T1W1: Hypo/Iso intensity.
b. T2WI: Capsule: Iso/Hypointense.
c. Centre: Hypo/Hyperintense.

3. Enhancement characteristics

a. Well-defined, thick, complete capsule of uniform or non-uniform thickness and smooth or irregular inner wall.

4. MRS

b. Ring (capsular)/solid enhancement.
a. Presence of lipid peak.
b. Cho: $\operatorname{Cr}(1.78 \pm 0.45)$.

\section{MR Morphologic types of Intracranial Tuberculomas} Non-Caseating Tuberculoma

Low signal intensity on T1WI and high signal intensity on T2WI with homogenous enhancement on post-contrast images.

\section{Caseating Tuberculoma a with Solid Centre}

Low/Intermediate signal intensity on T1WI and T2WI with rim enhancement on post contrast images.

\section{Caseating Tuberculoma with Liquid Centre}

Low-to-intermediate signal intensity on T1WI and hyperintense on T2WI and show rim enhancement on postcontrast images.

\section{MR Features of Meningitis}

1. Hydrocephalus (Communicating or non-communicating).

2. Enhancement of the meninges predominantly basal cisterns, suprasellar cisterns and other cisterns.

3. Features of infarcts/vasculitis.

\section{MR Features Associated with Abscess}

1. Tubercular abscess has smoother enhancing walls, mass effect and edema.

2. No amino acid peak at $0.9 \mathrm{ppm}$.

To conclude MRI along with MRS is an excellent, noninvasive investigation providing us complete morphological pattern of an intracranial tuberculoma and its various associated complications.

\section{REFERENCES}

1. Dastur HM. Tuberculoma review with some personal experience. Neuro India 1972;20:111.

2. Bagchi A. The intracranial tuberculomas. J Ind Assn 1961;37:429-433.

3. Rammurthi B. Experiences with tuberculomas of the brain. Ind J surg 1956;18:452.

4. Salgado $\mathrm{P}$, Del Brutto $\mathrm{OH}$, Talamás $\mathrm{O}$, et al. J Intracranial tuberculoma: MR imaging: Neuroradiology. 1989;31(4):299-302. PMID:2797420

5. Uysal G, Kose G, Guven A, et al. Magnetic resonance imaging in diagnosis of childhood central nervous system tuberculosis infection. 2001;29:148-153.

6. Bhargava S, Tondon PN. Intracranial tuberculomas: A CT study. Br J Radiol 1980 Oct;53(634):935-45.

7. Vimala J, Dinakar I. Tuberculomas of the brain. Ind J tub XXVI: No 1.

8. Garg RK. Diagnosis of intracranial tuberculoma. Ind J Tub 1996;43:35-109.

9. Reddy DJ. Tuberculoma of the brain. Ind J surg 1951;13:138.

10. Asenzo A, Valladares H, Fierro J. Tuberculomas of braina report of 159 cases. Arch of neurology and psychiatry. 1951;65:146.

11. Jinkins JR. Computed tomography of intracranial tuberculosis. Neuroradiology 1991;33:126-135.

12. Chang KH, Han MH, Roh JK, et al. Gd DTPA enhanced MR imaging in intracranial tuberculosis, Neuroradiology. 1990;32:19-25, 107.

13. Ozates M, Kemaloglu S, Gurkan F, et al. CT of brain in tuberculous meningitis. A review of 289 patients. Acta radiol 2000;41:31-171. 
14. Gupta RK, Roy R, Dev R, et al. Finger printing of mycobacterium tuberculosis in patients with intracranial tuberculomas by using in vivo, ex-vivo, and in vitro magnetic resonance spectroscopy. Mag reson med 1996;36:829-33.
15. Rim Abdelmalek, Fakher Kanoun, Badreddine Kilani, Hanène Tiouiri, Faycal Zouiten, Ahmed Ghoubantini, et al. Tuberculous meningitis in adults: MRI contribution to the diagnosis in 29 patients. International Journal of Infectious Diseases, Vol. 10, Issue 5, p372-377 Published in issue: September, 2009. 